\title{
On the use of the adessive case in Tver Karelian
}

\author{
NICKLAS ORANEN \\ University of Helsinki
}

\begin{abstract}
This study provides a descriptive account of the adessive case in the endangered and scarcely documented Tver Karelian variety of the Karelian language. The investigation provides not only an overview of the many functional uses of the case in question, but also comparisons to Finnish and Estonian, as well as Russian. The adessive case is historically associated with external location but has acquired a wide range of other uses not directly related to location, including temporal, instrumental, possessive, dative, and experiential functions. The case is even used to mark direct and oblique objects of certain verbs. Some of these functions are shared by the adessive case in other Finnic languages, including Finnish and Estonian, while other functions that set Tver Karelian apart from these relatives appear to have developed under the influence of Russian with which the language has a long history of contact.
\end{abstract}

Keywords: case marking; adessive case; language contact; Tver Karelian; Finnish; Estonian; Russian

\section{Introduction}

Tver (Tver') Karelian is an endangered variety of the Karelian language spoken in the central regions of the Tver' Oblast, Russia. It is the most southernly spoken Finnic language, forming a linguistic enclave surrounded by Russian-speaking areas located some two hundred kilometres 
from Moscow. The language possesses five so-called local cases, which are used for expressing various spatial relations. One of these cases, the adessive case, is notable for having developed a wide range of functions not directly related to location. Some of these functions of the adessive case are shared by genealogically related languages, including Finnish and Estonian, while other functions set Tver Karelian apart from these relatives. Functions that differentiate Tver Karelian from Finnish and Estonian can in some instances be attributed to influence from Russian, with which the language has been in continuous contact for centuries. Thus, the objective of this study is essentially three-fold. First and foremost, it provides a descriptive account of the functional uses of the adessive case in Tver Karelian, which have hitherto remained uninvestigated. Second, it relates these uses and the language itself to the more extensively described Finnic languages Finnish and Estonian. Third, it addresses potential Russian influences upon the use of the adessive case in Tver Karelian. In comparison to many of its Karelian and more distant Finnic relatives, Tver Karelian is strikingly underdescribed, with very few linguistic studies of the language in existence. Consequently, this study provides a rare contribution to the morphosyntactic research of the language in question.

Karelian dialects spoken in the Tver Oblast are not uniform, neither in terms of phonology, grammar, nor vocabulary (for an overview, see Bubrih et al. 1997). The epithet "Tver Karelian" is therefore based primarily on geography, and only secondarily on dialectal differences. Three major dialectal groupings of Tver Karelian are traditionally recognised: Ves'egonsk, Tolmači, and D’orža, forming a rather loose dialect continuum stretching from north to south (see, e.g., Wiik 2004, Novak 2016: 20). The second grouping is the focus of this study, while the other two dialectal groupings - Ves'egonsk and D’orža - are not discussed further. Thus, in this study "Tver Karelian" refers to Tolmači Karelian, specifically the dialect spoken in the Likhoslavl' district. The data upon which the analysis is based as well as the various examples presented in the study have all been obtained and recorded by the author during fieldwork in 
the aforementioned district, specifically in the villages Tolmači, Vasil'ki, Nazarovo, Zalazino, and Anankino. All data and examples in Finnish, Estonian, and Russian have been cross-checked by native speakers and in relation to prominent reference grammars, e.g., ISK (2004), EKG (1995), RG (1980/2005), respectively.

Section 2 provides a historical background and overview of the adessive case among the Finnic languages, and also addresses some of the languages' shared innovations concerning non-locative uses of the case. Sections 3 and 4 exemplify the use of the Tver Karelian adessive case in spatial and temporal expressions, and instrumental and possessive expressions, respectively. These uses are reflected to varying degrees in Finnish and Estonian, and certain parallels can even be drawn to Russian. Section 5 explores various dative and experiential functions, which are invariably marked by the adessive case in Tver Karelian, but show much variation in terms of case marking in Finnish and Estonian. While certain dative and experiential uses of the adessive case in Tver Karelian can be explained by the loss of a distinct allative case, it is noteworthy that the adessive case in the language appears to precisely mirror the dative case in Russian. Finally, section 7 discusses additional uses of the adessive case in Tver Karelian, none of which are widely shared by Finnish and Estonian. These uses are analogous to both dative and instrumental case uses in Russian. Finally, section 8 provides a conclusion and summary of the various functions of the adessive case in Tver Karelian in comparison to the case marking of corresponding functions in Finnish, Estonian, and Russian.

Other Karelian varieties resemble Tver Karelian to differing extents regarding their use of the adessive case. Unfortunately, however, it has not been possible to provide a comprehensive comparison between the use of the adessive case in Tver Karelian and in other Karelian varieties due to a lack of available data. However, a few comments regarding some similarities between Tver Karelian and certain closely related Karelian relatives (specifically North Karelian, Tikhvin Karelian, and Valdaj Karelian) are provided in the conclusion. 


\section{Historical background}

The adessive case in Tver Karelian represents one of six so-called local cases reconstructed for Proto-Finnic (PF) (Laakso 2001: 196f.; see also, e.g., Aikio \& Ylikoski 2016). Historically, these cases formed a double tripartite system with three external local cases indicating static external location (adessive *-llA), motion towards an external location (allative ${ }^{*}-l e n$ ), and motion away from an external location (ablative ${ }^{*}-l t A$ ); and three internal local cases indicating static internal location (inessive ${ }^{*}-s s A$ ), motion towards an internal location (illative ${ }^{*}-s V n$ ), and motion away from an internal location (elative ${ }^{*}$ stA). The Proto-Finnic cases are in turn derived from a combination of various Proto-Finno-Ugric (PFU) markers indicating external $\left({ }^{*}-l\right)$ and internal $\left({ }^{*}-s\right)$ location, and locative $\left({ }^{*}-n A\right)$, lative $\left({ }^{*}-n\right)$, and separative manner $\left({ }^{*}-t A\right)$. The relationships between the various Proto-Finnic and Proto-Finno-Ugric markers are illustrated in table 1 below. Note the assimilation of $\mathrm{PF}{ }^{*}-l l A<\mathrm{PFU}$ ${ }^{*}-l+{ }^{*}-n A$.

TABLE 1. Origin of the Finnic local cases

\begin{tabular}{|c|c|c|c|}
\hline & $\begin{array}{l}\mathrm{PFU}^{*}-n A \\
\text { (Locative) }\end{array}$ & $\begin{array}{l}\mathrm{PFU}^{*}-n \\
\text { (Lative) }\end{array}$ & $\begin{array}{c}\text { PFU }^{*}-t A \\
(\text { Separative })\end{array}$ \\
\hline $\begin{array}{l}\text { PFU }{ }^{*}-l \\
\text { (External) }\end{array}$ & $\begin{array}{c}\mathrm{PF}^{*} \text {-llA } \\
\text { (Adessive) }\end{array}$ & $\begin{array}{l}\mathrm{PF}^{*} \text {-len } \\
\text { (Allative) }\end{array}$ & $\begin{array}{c}\mathrm{PF}^{*}-l t A \\
\text { (Ablative) }\end{array}$ \\
\hline $\begin{array}{l}\mathrm{PFU}^{*}-s \\
\text { (Internal) }\end{array}$ & $\begin{array}{c}\mathrm{PF}^{*} \text {-ss } A \\
\text { (Inessive) }\end{array}$ & $\begin{array}{l}\mathrm{PF}^{*}-s V n \\
\text { (Illative) }\end{array}$ & $\begin{array}{l}\mathrm{PF}^{*} \text {-st } A \\
\text { (Elative) }\end{array}$ \\
\hline
\end{tabular}

In the daughter languages of Proto-Finnic, the local cases have been retained to varying degrees. In Livonian, for instance, the external cases are no longer productive (Grünthal 2003: 27; Blokland \& Inaba 2018: 153), but both the external and internal cases remain productive in Finnish and Estonian. In most varieties of Karelian the allative case has merged with the adessive case, while the remaining cases remain functionally and morphologically distinct. This also applies to the southernly 
geographically discontinuous enclaves of Karelian proper represented by Tolmači Karelian, and its sister dialects Ves'egonsk and D'orža Karelian (Õispuu 1994: 164, 169), as well as Valdaj Karelian (Palmeos 1962: 24, $40 \mathrm{f}$.). Sporadic instances of a distinct allative case have been attested in Tikhvin Karelian (e.g. Rjagoev 1977: 63), but Larjavaara (1986: 419) suggests that these may be the result of Livvi (Olonets) Karelian influence. In Livvi Karelian the elative case has merged with the inessive case, while the illative case remains distinct. In Southeastern Livvi Karelian the adessive and ablative cases have merged, but the allative case remains distinct; while the internal cases have all merged in Northwestern Livvi Karelian (Larjavaara 1986: 416 f.). In addition to the retention, loss, and/or merging of the original Proto-Finnic local cases in the various descendant languages, several Finnic languages have also developed new cases that express location in one way or another. For an overview of such developments, see, e.g., Grünthal (2003).

The local cases of Tver Karelian, Finnish, and Estonian are given in table 2 below. Note that all case suffixes in Tver Karelian but the illative have palatalised allomorphs not included in the table. Note also the sound change from Proto-Finnic ${ }^{*}-s$ - to $-h$ - in the Finnish and Tver Karelian illatives, i.e. $-(h) V n$ and $-h\left(<^{*}-h V n\right)$, respectively. The Estonian illative -sse is "a new illative" which has replaced "the old illative type, where the ending has (almost) completely worn off," that is - $\varnothing$ (Laakso 2001: 197).

TABLE 2. Local cases in Tver Karelian, Finnish, and Estonian

\begin{tabular}{|l|c|c|c|c|c|c|}
\hline Language & Adessive & Allative & Ablative & Inessive & Illative & Elative \\
\hline Tver Karelian & \multicolumn{2}{|c|}{$-l l A$} & $-l d A$ & $-\check{s} \check{s} A /-s s A$ & $-h$ & $-\check{s} t A /-s t A$ \\
\hline Finnish & $-l l A$ & $-l l e$ & $-l t A$ & $-s s A$ & $-(h) V n$ & $-s t A$ \\
\hline Estonian & $-l$ & $-l e$ & $-l t$ & $-s$ & $-\varnothing /-s s e$ & $-s t$ \\
\hline
\end{tabular}

Evidently, the adessive case is historically used to express physical external location, and this function remains productive in Finnic languages 
ON THE USE OF THE ADESSIVE CASE IN TVER KARELIAN

that have retained the case. In addition to this historical use the adessive case has adopted a wide range of other functions in many Finnic languages. Most notably, the adessive case is widely used to denote time, possession, instruments, and what can be described as various "dative" functions (cf. Seržant 2015). The use of the adessive case to denote time is a natural extension of the locative function, which is also used for abstract locations; and the same is true for the possessive and instrumental uses, according to Huumo (1996: 88 ff.). The latter domain shifts are discussed in more detail below.

The Proto-Finnic case suffix ${ }^{*}-n$, reflected as the genitive case in Modern Finnic languages, is homonymous and possibly identical with the "instructive case" used for marking instruments (see, e.g., Ravila 1941: 77 ff.; Itkonen 1966: 267; Korhonen 1991: 5). The instrumental function of ${ }^{*} n$, however, is no longer productive though it can still be found in some lexicalised expressions (e.g. Finnish jalan 'on foot'). In many Finnic languages, including Tver Karelian, the instrumental functions have been acquired by the adessive case. Note, however, that instruments in some Finnic languages can also be marked by recently grammaticalised comitative cases, as in Estonian and Livonian, or by postpositions. The adessive case has also come to be used in predicative possession in most Finnic languages, while attributive possession is usually expressed by genitive $-n$.

Huumo (1996) hypothesises that the adessive case adopted the abovementioned functions gradually. The possessive function may have originated in animate nouns which would first have had "the semantic function of expressing concrete, physical possession, but later acquired a 'proper' possessive meaning of indicating ownership" (Huumo 1996: 81). Likewise, Huumo argues that "[t]he actual spread of the adessive into the instrumental function may have occurred first in cases where the adessive indicated an entity which could be conceptualised either as a location or as an instrument" (op.cit. 86). See the illustrative examples from Finnish in (1) and (2), respectively. 
(1) Isä-llä on kirves.

father-ADE be.3sg axe

'Father has an axe [in his hands].' > 'Father owns an axe.' (Huumo 1996: 81)

(2) Isä lämmitt-i ruoa-n tule-lla.

father warm-PST.3SG food-ACC fire-ADE

'Father warmed the food on the fireplace.' > '[---] with the fire.' (Huumo 1996: 86)

Many of the dative functions of the adessive case in Tver Karelian and other Karelian varieties can be explained by the abovementioned loss of the allative case, which is traditionally associated with the marking of recipients, beneficiaries, and other types of goals. For this reason, the suffix - $l l A$ is sometimes called "adessive-illative" in Karelian dialects in which the adessive and illative cases have merged (see, e.g., Zajkov 1999, 2013), yet the term "adessive" is retained in this study for historical and etymological reasons. Regardless of terminology, it has been widely argued that the use and functions of the adessive case (and the allative case where retained) in Finnic languages are in many ways similar in use and function to the dative and instrumental cases in Russian and the Baltic languages. These languages have a long history of contact, and it has been suggested that some of the similarities between the languages represent areal tendencies (see, e.g., Dahl \& Koptjevskaja-Tamm 2001; Seržant 2015, 2016; Mazzitelli 2017). Contact between Tver Karelian and Russian has been particularly intense during the last four centuries, during which Tver Karelian has constituted an enclave surrounded by the Russian language. This contact can explain certain functional uses of the adessive case in Tver Karelian which are not shared by Finnish and Estonian, as further noted in sections 6 and 7. 


\section{Spatial and temporal domains}

The historical use of the adessive case in the expression of external location has been retained and remains highly productive in Tver Karelian (3). In addition to this function, the adessive case is also used to express motion towards an external location (4) due to the loss of a distinct allative case, as discussed in section 2 above. Thus, locative nominals marked by the adessive are often semantically ambiguous in isolation, and ambiguity is resolved by further context or by verbal semantic meaning.

(3) Mie el-ii-n ka tua-lla lesnoi-ll[a] uuliča-ze-lla 1SG live-PST-1SG DP that-ADE forested-ADE road-DIM-ADE toize-lla.

other-ADE

'I lived on that other small forest road right over there'

(4) Jove-lla hüppel-i-mä, konža pikkaraze-t ol-i-ma. river-ADE run-PST-1PL when small-PL be-PST-1PL 'We would run down to the river when we were small.'

In addition to concrete physical external location, the adessive case is also used to indicate more abstract location. In (5), for instance, the adessive case is used to indicate that the speaker is 'on a pension', in other words 'retired'. A similar expression is lähtie pensiillä 'to leave onto a pension', i.e. 'to get retired'. Other examples of abstract external location include, e.g., männä miehellä 'to get married' (lit. 'to go to a man'), hüpellä peremenalla 'to run about during recess' (lit. 'to run about on recess'), and kävellä kursiloilla 'to attend courses' (lit. 'to go on/to courses').

(5) Soroklet ruavo-i-n bolniča-šša, nüt ole-n pensii-llä. forty years work-PST-1SG hospital-INE now be-1SG pension-ADE 'I worked in the hospital for forty years, [and] now I am retired.'

The use of the adessive case to express abstract external location has also been extended to temporal expressions. The adessive case is used for seasons of the year (kežällä 'in summer', keviällä 'in spring', šügüžüllä 'in autumn', talvella 'in winter'), months (e.g. dekabralla or dekabrilla 
'in December'), weeks (e.g. kolmannella nedelillä 'in/on the third week'), and times of the day (e.g. huomnekšella 'in the morning', päivällä 'during the day, at daytime', illalla 'in the evening', and üöllä 'at night'). The expression 'in spring' is further illustrated in (6).

(6) Keviä-llä ka ogordo-i-nke zavodi-t ruada-ma-h. spring-ADE DP garden-PL-COM begin-2SG work-INF-ILL 'In spring you begin to work with/in the (kitchen) gardens.'

As already noted in the introduction, Finnish and Estonian behave in a similar manner when it comes to spatial and temporal expressions, also employing the adessive case. Having retained the allative case, motion towards an external location continues to be expressed by this case in these languages, unlike in Tver Karelian: Finnish juoksimme jovelle 'we ran to the river,' Estonian jooksime jõele 'id.' cf. (4) above. Spatial functions - whether concrete or abstract - are expressed by various prepositions in Russian, notably na and $v$ (cf. na lesnoj doroge 'on the forest road', my begali na reku 'we would run to the river', na pensii 'on a pension'). The same is true for certain temporal functions (cf. $v$ dekabre in December'), while others are expressed by the instrumental case (cf. $v$ tretej nedele 'in the third week', dnëm 'during the day', vesnoj 'in spring').

\section{Instrumental and possessive domains}

The adessive case in Tver Karelian is also widely used to mark instrumentals, as well as possessive relationships. Both functions seem to have developed from the spatial uses, as argued in section 2. Instruments marked by the adessive case can be either concrete (7), or more abstract, as in the expressions kirjuttua latinicalla 'to write using the Latin script' and ruadua dizelillä 'to run (lit. work) on diesel (e.g. car, tractor)'. Methods of transport are also marked by the adessive case, for example ajella mašinalla 'to drive around in a car' and čurissa regüzellä 'to ride a sleigh'. In other words, the adessive case can mark entities by means of which an action is accomplished. Finnish is similar to Tver Karelian in this respect 
ON THE USE OF THE ADESSIVE CASE IN TVER KARELIAN

(e.g. kaivaa lapiolla 'to dig with a spade'), while Estonian tends to employ the comitative case for this function (e.g. kaevama labidaga 'id.').

(7) A riädü-löi-h varoin käzi-löi-llä zuastupa-lla kaiva-n but furrow-PL-ILL for hand-PL-ADE spade-ADE dig-1SG 'But for the furrows [in the kitchen garden], I dig [them] by hand with a spade.'

A typical possessive construction in Tver Karelian is illustrated in (8) below, in which the copula olla 'to be' links a possessor marked by the adessive case and a possessee marked by the partitive case. If the clause in (8) were affirmative, the possessee would be marked by the nominative (e.g. meilä on kolhoza 'we have a farming collective'). Finnish and Estonian behave in a similar manner. In Russian the preposition $u$ 'at' precedes the possessor, which is marked by the genitive case (cf. $u$ nas byl kolkhoz 'we had a farming collective'). The Finnic and Russian possessive constructions are reminiscent of each other, all employing marking traditionally associated with location. Mazzitelli (2017: 46) notes that the possessive construction involving the preposition $u$ 'at' likely dates back to Late Proto-Slavic (see also McAnallen 2011), but that its use has declined in all other Slavic languages but Russian, in which it has been retained and strengthened due to prolonged contact with the Finnic languages.

(8) A nüt kolhozu-a ei ole mei-lä tiälä. but now farming.collective-PART NEG.3 be.CNG 1PL-ADE here 'But now we don't have a farming collective here [anymore].'

The adessive case is also used for more abstract expressions of possession in Tver Karelian, for instance in age expressions (e.g. miula on ... vuotta 'I am ... years old'). This reflects the use of the dative case in Russian (e.g. mne ... let 'id.). The adessive case can also employed as an alternative to the nominative case in Estonian (e.g. mul on ... aastat or mina olen ... 'id.), while the "possessor" of age is most commonly marked by the nominative case in Finnish (e.g. minä olen ... (vuotta) 'id.). 


\section{Dative and experiential domains}

Following Seržant (2015), the dative domain here refers to functions widely associated with "dative semantics", e.g. recipients, beneficiaries, and experiencers of various sorts. In Tver Karelian these tend to be marked by the adessive case. The marking of a recipient is illustrated in (9) below, while the marking of a beneficiary is illustrated in (10). As discussed in section 2, these functions were acquired by the adessive case in many Karelian varieties, including Tver Karelian, following the loss of the allative case, which is otherwise historically associated with the marking of recipients and beneficiaries. The allative case continues to be used for these functions in Finnish (heille 'to them', meille 'to us') and Estonian (neile 'to them', meile 'to us'), while the dative case is used in Russian (im 'to them', nam 'to us').

(9) Naiččiče-ttih, anne-ttih ka hei-lä ka tämä-n marry-PST.3PL give-PST.3PL DP 3PL-ADE DP this-ACC perti-n.

house-ACC

'They got married, [and] they were given this house right here.'

(10) Jogo päivi-ä mei-lä jäte-ttih avuame-n. every day-PART 1PL-ADE leave-PST.3PL key-ACC 'They would leave the key [to the club house] for us every day'

The adessive case can also be used in what might be characterised as external possession (see, e.g., Seržant 2016). In (11) below, for instance, the speaker can be perceived as the possessor (i.e. mother) of brihane 'boy' (see the translation, 'my boy'). Alternatively, the speaker can also be considered a beneficiary (as the birth was a fortunate event), or even an experiencer (having personally experienced the birth). In Estonian the speaker would also be marked by the adessive case (cf. mul sündis poeg 'my son was born', or 'I gave birth to a son'), while the allative case would be used in Finnish (cf. minulle syntyi poika 'id.). In Russian the speaker would appear in the genitive case preceded by the preposition $u$ 'at' (cf. $u$ menja rodilsja syn 'id.). 
ON THE USE OF THE ADESSIVE CASE IN TVER KARELIAN

(11) Šidä ka miu-la brihane šündü $\quad$ jo tiälä.
then DP 1SG-ADE boy be.born.PST.3SG already here
'[And] then my boy was already born right here [in this town].'

Entities experiencing various types of state also tend to be marked by the adessive case in Tver Karelian, for instance experiencers of corporal sensations, e.g. miula on vilu 'I am cold'. Again, the adessive case is also employed for this function in Estonian (cf. mul on külm 'id.), while either the adessive case or the genitive case might be used in Finnish (cf. minulla/minun on kylmä 'id.). The dative case is needed for such experiencers in Russian (cf. mne kholodno 'id.). Another kind of experience is illustrated in (12), in which the third person plural experiencer is marked by the adessive case and linked to an experience of facility by the copula olla 'to be'. For such an experiencer, the genitive case would be preferred in Finnish (cf. heidän on helpompi 'it is easier for them'), although some speakers may accept the allative case (cf. heille on helpompi 'id.). In Estonian there is some variation between the adessive and allative cases (cf. neil/neile on parem 'id.), while the dative case would be used in Russian (cf. im legče 'id.).

(12) Hei-lä on kebie-mbi paissa hormi-ksi.

3PL-ADE be.3SG easy-COMPR speak.INF Russian-TRSL

'It is easier for them to speak (in) Russian.'

In Tver Karelian the adessive case is also used to mark the experiencer of certain verbs of obligation, wish (or desire), and liking. The verb pidiä in the sense of obligation is illustrated in (13) below, while the verbs tahottua 'to want' and mieldüö 'to please' (or 'to like') are illustrated in (14) and (15), respectively. The partitive case has also been attested for the experiencers of the latter verb in place of the adessive case (cf. meidä miellüttih 'we liked'). Such "duty and obligation constructions" are discussed in a broader Karelian context by Sarhimaa (1999), who also investigates Russian influences thereupon. It should be noted that Tver Karelian also possesses the semantically similar verbs tahtuo 'to want' and šuata 'to like' which are conjugated according to the number and person of the 
experiencer, which itself is in the nominative case; cf. hiän tahtou 'he wants', müö šuačemma 'we like'.

(13) Häne-llä pid-i kezrätä štobi luadie materju-a [---] 3SG-ADE must-PST.3SG spin.INF in.order.to make.INF fabric-PART 'She had to spin [yarn] in order to produce fabric.'

(14) A nütten, nüt vet' nike-ll[ä] ei tahota but now now well nobody-ADE NEG.3 want.CNG ruadua, nike-llä. work.INF nobody-ADE

'But now, you see, now nobody wants to work, nobody'.

(15) Mei-lä lapšs-illa ülen miellü-ttih pruaznika-t. 1PL-ADE child-PL-ADE very please-PST.3PL holiday-PL.NOM 'We children really liked the holidays.'

The modal verb pidiä 'must' has synonymous cognates in both Finnish (pitäa) and Estonian (pidama), but the verb behaves slightly differently in these languages. In Finnish the experiencer is marked by the genitive case and the verb is invariably conjugated in the third person singular (cf. hänen pitää 'he must'), while in Estonian the verb is conjugated according to the experiencer, which is in the nominative case (cf. ta peab 'id.). The semantically similar Finnish verb täytyä 'must' behaves like pitää. The experiencer in expressions of obligation is marked by the dative case in Russian (cf. ети nado or eтu neobkhodimo 'id.). The experiencer of the Finnish verb haluttaa 'to want' (cf. Tver Karelian tahottua 'id.) is marked by the partitive case, while the experiencer of verbs like haluta and tahtoa 'id.' (cf. Tver Karelian tahtuo 'id.) is marked by the nominative case. In a similar manner, the experiencer of the Russian verb khotet'sja 'id.' is marked by the dative case, while the experiencer of the verb khotet' 'id.' is marked by the nominative case. In Estonian the experiencer of verbs of wish or desire is generally marked by the nominative case (e.g. soovima and tahtma 'id.). Experiencers of verbs of liking in Finnish are normally marked by the nominative case (e.g. pitää in the sense 'to like', tykätä 'id., mieltyä 'to grow fond of'), although a few verbs of this type 
require partitive case marking (e.g. miellyttää 'to please, like'). In Estonian the experiencer of the verb meeldima 'to please, like' is marked by the allative case (cf. meile meeldisid pühad 'we liked the holidays'), while in Russian the experiencer of the verb nravit'sja 'to please, like' is marked by the dative case (cf. nam nravilis' prazdniki 'we liked the holidays').

\section{Additional uses}

The adessive case in Tver Karelian is also used to mark what might be characterised as the direct object of a small group of verbs. Verbs of this type are mostly of Russian origin, for example vierie 'to believe, trust' (16) and zaviiduija 'to envy' (17), as well as sluužie 'to serve', mešaija 'to bother', nadoimie 'to pester', i.a. These verbs are clear borrowings of the semantically identical Russian verbs verit', zavidovat', služit', mešat', and dialectal nadonjat' (stem nadojm-), respectively. In Russian the verbs all require a direct object in the dative case (cf., e.g., verit' učitelju 'to believe a/the teacher', zavidovat' molodjožju 'to envy the youth'). The direct objects of the corresponding verbs are all marked by the partitive case in both Finnish (cf. uskoa 'to believe, trust', kadehtia 'to envy', palvella 'to serve', häiritä 'to bother', kiusata 'to pester') and Estonian (cf. uskuma 'to believe, trust', kadestama 'to envy', teenima 'to serve', segama 'to bother', kiusama 'to pester').

(16) Vier-i-mä oma-lla učitela-lla. believe-PST-1PL Own-ADE teacher-ADE 'We believed [our] own teacher.'

(17) I ruadu-o eu, takšto nuor-i-lla mie and work-PART be.not so young-PL-ADE $1 \mathrm{SG}$ $e-n \quad z a v i i d u i c ̌ e$.

NEG-1SG envy.CNG

'And there is no work, so I do not envy young people.'

Only two verbs of native origin have hitherto been attested with adessive direct object marking in Tver Karelian: auttua 'to help' and käškie 'to order'. The use of these verbs is exemplified in (18) and (19), respectively. 
The dative case is also used for the direct objects of these verbs in Russian (cf. pomogat' drug drugu 'to help each other', komu-to prikazat' 'to order somebody'). In Finnish the partitive case is required for the direct object of both verbs (cf. auttaa toisiaan 'to help each other', käskeä jotakuta 'to order somebody'); while in Estonian the partitive case is required for the former (cf. aitama teineteist 'to help each other'), but the partitive or the adessive case for the latter (cf. käskima kedagi/kellelgi 'to order somebody'). This use of the adessive case in Tver Karelian is closely related to the dative functions discussed in the previous section.
(18) Aute-ttih toine toize-lla issuttua juablokku-a. help-PST.3PL each.other-ADE plant.INF potato-PART '[They] helped each other plant potatoes.'
(19) Šidä tuatto käšk-i miu-la tulla kodi-h. then father order-PST.3SG 1SG-ADE come.INF home-ILL 'Then [my] father ordered me to come home.'

The adessive case is also used to mark various oblique-like verb-dependent roles, for instance the illness with which one falls ill (20), sensation of smell (21), and that in which one is engages (22). The roles are all marked by the instrumental case in Russian (cf. zabolet' infarktom 'to get an infarct', paxnut' pirožkami 'to smell of pierogis', čem-to zanimat'sja 'to be engaged in something'). In Finnish the illative case is used for the first role (cf. sairastua sydänkohtaukseen 'to get a heart attack'), the allative or the ablative case for the second role (cf. haista/tuoksua piirakoille/piirakoilta 'to smell of pierogis'), and the partitive case for the third role (cf. harrastaa jotakin 'to be engaged in something'). Note that a construction with the verb 'to get' is also often used with regard to infarcts and heart attacks in Russian (cf. polucit' infarkt 'to get an infarct') and Finnish (cf. saada sydänkohtaus 'to get a heart attack'). This is also the most commonly used construction in Estonian (cf. saama südameatakki 'id.). The second role is marked by a postposition in Estonian (cf. lõhnama piruka järgi/järele 'id.), while the third role is marked by the partitive case (cf. harrastama midagi 'to be engaged in something'), like in Finnish. 
(20) Mužikka infarkta-lla läzeüdü.

husband infarct-ADE fall.ill.PST.3SG

' $[\mathrm{My}]$ husband had a heart attack.'

(21) A konža tule-t kodi-h, šielä haizu-u piirua-lla. and when come-2SG home-ILL there smell-3SG pierogi-ADE 'And when you came home, it would smell of pierogis'. [historic present]

(22) Mi-llä tämpiänä zanimaiččieče-t?

what-ADE today engage.in-2sG

'What are you up to today?'

The Tver Karelian verbs voshiššiččiečie 'to admire, be carried away (by)' and torguija 'to trade, deal (in)' behave like läzeüdüö 'to fall ill (with)', haizuo 'to smell (of)', and zanimat'sja 'to be engaged (in);' also mirroring instrumental case marking in Russian (cf. voskhiščat'sja and torgovat', respectively). The adessive case is also sometimes used to indicate the language in which one talks with the verb paissa 'to talk, speak', as exemplified in (23). More frequently, however, the language is in the translative case, e.g. paissa karielakši 'to speak Karelian;' see also (12).

(23) Koi-ssa pidä-is' paissa kariela-n kiele-llä. home.INE must-COND.3SG speak.INF Karelian-GEN language-ADE 'One should speak Karelian at home.'

In Russian a language being spoken would generally be represented by an adverb (cf. govorit' po-karel'ski 'to speak Karelian'), although it may be marked by the instrumental case in some marginal contexts (cf. govorit' karel'skim jazykom 'id.). The adessive case is only used in restricted contexts in Finnish and Estonian, in which the partitive case is generally preferred (cf. puhua karjalan kieltä and rääkima karjala keelt 'id., respectively). This use of the adessive case in Tver Karelian can alternatively also be perceived as an abstract instrumental. 


\section{Conclusion}

As evident in the preceding sections, the adessive case has at least seven different functions in Tver Karelian, being a marker of i) location, ii) time, iii) instruments, iv) possession, v) various dative and experiential roles, vi) direct objects of certain verbs, and vii) oblique objects of certain verbs. These functions are summarised in table 3 below, which also shows the corresponding case marking of each function in Russian, Finnish and Estonian. Note that external possession is here grouped together with general possession and possession of age, and not the dative functions, as external possession has characteristics of both possession and experience (see section 5). The number(s) under the heading "Exx." refer(s) to one or more examples illustrative of a particular function.

As explained in section 2, the historical function of the adessive case among the Finnic languages is to indicate location, although the temporal, instrumental, and possessive functions of the case appear to have developed early in the history of the languages. The similarities in the case marking of these functions in Tver Karelian, Finnish and Estonian are therefore not surprising nor unexpected. Of more interest is the consistent use of the adessive case in Tver Karelian to mark dative and experiential functions, as well as its use in the marking of certain direct and oblique objects. Similarities and disparities in the case marking of these particular functions in Tver Karelian, Finnish, and Estonian are discussed in more detail below.

As discussed in section 5, the adessive case in Tver Karelian has at least seven different dative/experiential functions, being used to mark i) recipients and beneficiaries; ii) external possessors, iii) experiencers of certain states, e.g. 'he is cold;' iv) experiencers of certain capabilities, e.g. 'it is easier for him to do something;' v) experiencers of verbs of obligation, e.g. 'he must do something;' vi) experiencers of certain verbs of wish, e.g. 'he wants to do something;' and vii) experiencers of certain verbs of liking, e.g. 'he likes something'. Some of these functions 
TABLE 3. Comparison of functions and case marking

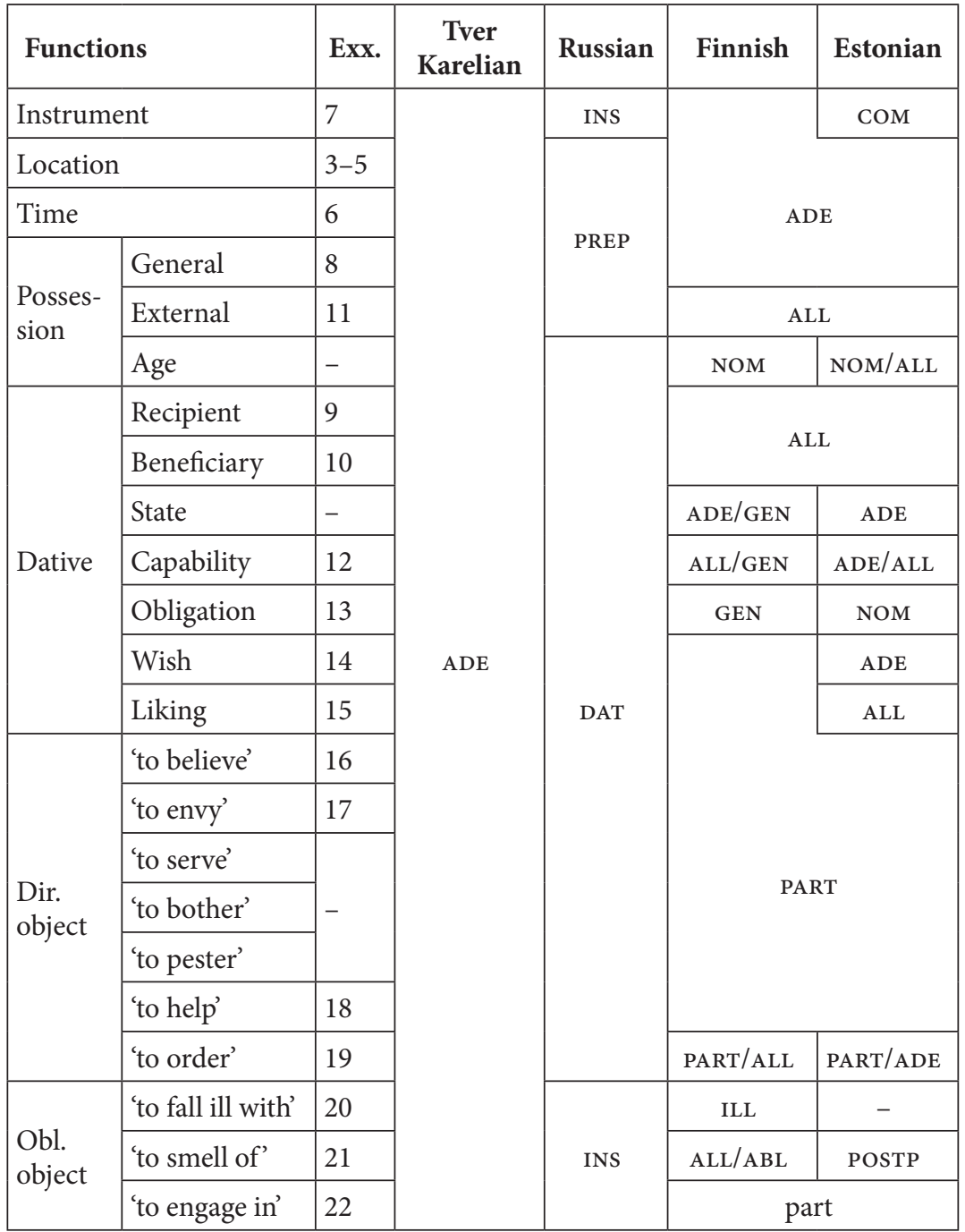


are reflected by the allative case in Finnish and Estonian, notably the first, second, and third functions. The same is true for the fourth function, although the adessive case can alternatively be used in Estonian as well. The fifth, sixth, and seventh functions of the adessive case in Tver Karelian show more variation in Finnish and Estonian. The fifth function is marked by the genitive case in Finnish, but the nominative case in Estonian; while the sixth and seventh functions are marked by the partitive case in Finnish, but the adessive or allative case in Estonian. The discrepancies between Tver Karelian on the one hand and Finnish and Estonian on the other hand can in many cases be explained by the loss of the allative case as a distinct case in Tver Karelian, and the subsequent acquisition of its functions by the adessive case, as explained in section 2. Nevertheless, Tver Karelian is notable for its homogeneous marking of all dative/experiential functions, unlike Finnish and Estonian which show considerable variation. The uniform marking in Tver Karelian is likely influenced - or at least reinforced - by the consistent use of the dative case in Russian for the functions in question.

Tver Karelian also differs from Finnish and Estonian in the use of the adessive case to mark the direct and oblique objects of certain verbs, as argued in section 6. In Tver Karelian the adessive case is, for instance, used to mark the direct objects of the verbs vierie 'to believe', zaviiduija 'to envy', sluužie 'to serve', mešaija 'to bother', nadoimie 'to pester', auttua 'to help', and käskkie 'to order', as well as the oblique object of the verbs läzeüdüö 'to fall ill (with)', haizuo 'to smell (of)', and zanimaiččiečie 'to engage (in)', i.a. This use of the adessive case in Tver Karelian is also likely an influence from Russian, in which the direct objects in question are marked by dative case, and the oblique objects by the instrumental case. In Finnish and Estonian, on the contrary, the direct object of all the corresponding verbs in question but 'to order' are marked by the partitive case (or in some contexts, potentially the nominative or accusative-genitive case, according to differential object marking). The direct object of 'to order' (i.e. the person being ordered) is in Finnish generally marked by the partitive case, and marginally by the allative case; and 
ON THE USE OF THE ADESSIVE CASE IN TVER KARELIAN

in Estonian by the partitive or adessive case. The oblique object of 'to engage (in)' is also marked by the partitive case in Finnish and Estonian. The oblique objects of 'to fall ill (with)' and 'to smell (of)' are in Finnish marked by the illative case, and the allative or ablative case, respectively; while the meanings are typically expressed by analytic constructions in Estonian.

Evidently, the many functional domains of the adessive case in Tver Karelian can be explained by a combination of diachronic development and language contact. The various uses of the adessive case influenced by Russian are remarkably consistent among speakers owing to widespread - if not universal - bilingualism among Tver Karelians in the two languages. Further research is required to determine how and to what degree the use of the adessive case in Tver Karelian differs from its use in other Karelian varieties, particularly in other varieties of Karelian proper. Zaikov (2013: $96 \mathrm{ff}$.) lists twelve uses of the adessive case in North Karelian, which roughly encompass the spatial, temporal, instrumental, possessive, and dative uses of the adessive case described for Tver Karelian in this study, but not the experiential uses. Zaikov also notes that the adessive case in North Karelian can be used alongside certain pre- and postpositions, including the preposition jälkeh 'after' and the postposition piällä 'on (top of)' (id.: 98). This phenomenon has been observed in Tver Karelian as well, but lack of data has prevented it from being investigated further. Rjagoev (1977: 91 f.) lists eleven uses of the adessive case in Tikhvin Karelian, which roughly encompass the same uses as in North Karelian in addition to experiential uses. Finally, Palmeos (1962: $32 \mathrm{ff}$.) lists twelve uses of the adessive case in Valdaj Karelian largely corresponding to the uses in Tikhvin Karelian. Interestingly, Palmeos lists another two uses that resemble the use of the adessive case in direct and oblique object marking in Tver Karelian, and even discusses Russian influence explicitly, albeit very briefly (id.: 34 ). Three of Palmeos' seven examples in Valdaj Karelian bear some resemblance to examples presented for Tver Karelian in this study: ei uškuota briharлa '(they) don't believe the boy' or 'the boy is not believed', họän miила ei auta 'he 
doesn’t help me', hüvällä haiźow '(it) smells good' (ibid.); cf. examples (16), (18), (21), respectively. It should be noted that Rjagoev (1977) provides one example of oblique object marking, but does not address the matter explicitly: ruvalla zańimaiččiečči ' [now and then he] was engaged in (activities involving) sap(wood)' (id.: 92); cf. example (22).

Further research and more data is required to determine and assert the more precise extents of the adessive case's use in relation to direct and oblique object marking, both in Tver Karelian and in other Karelian varieties.

\section{References}

Aikio, Ante, Jussi Ylikoski 2016. The Origin of the Finnic l-Cases. - Fenno-Ugrica Suecana Nova Series 15, 59-158.

Blokland, Rogier, Nobufumi Inaba 2018. The 1-Cases in Courland Livonian. ESUKA/JEFUL 9 (2), 147-164. https://doi.org/10.12697/jeful.2018.9.2.07

Bubrih, Dmitrij B., Aleksandr A. Beljakov, Aleksandra A. Punžina 1997. Karjalan kielen murrekartasto ['The atlas of Karelian dialects']. Helsinki: SuomalaisUgrilainen Seura.

EKG 1995 = Mati Erelt, Reet Kasik, Helle Metslang, Henno Rajandi, Kristiina Ross, Henn Saari, Kaja Tael, Silvi Vare. Eesti keele grammatika I. Morfoloogia. Sõnamoodustus ['The grammar of the Estonian language I: Morphology. Word-formation']. Eesti Teaduste Akadeemia Eesti Keele Instituut. Tallinn.

Grünthal, Riho 2003. Finnic Adpositions and Cases in Change. Mémoires de la Société Finno-Ougrienne 244. Helsinki: Suomalais-Ugrilainen Seura.

Huumo, Tuomas 1996. Domain shifts and the grammaticalization of case: A case study of the Finnish adessive. - Folia Linguistica Historica XVII (1-2), 73-95. https://doi.org/10.1515/flih.1996.17.1-2.73

Itkonen, Erkki 1966. Kieli ja sen tutkimus ['Language and its study']. Helsinki: WSOY.

Korhonen, Mikko 1991. Remarks on the Structure and the History of the Uralic Case System. - Journal de la Société Finno-Ougrienne 83, 163-180.

Dahl, Östen, Maria Koptjevskaja-Tamm (Eds.) 2001. Circum-Baltic Languages. Vol. 1-2. Studies in Language Companion Series 54. Amsterdam/Philadelphia: John Benjamins Publishing Company. https://doi.org/10.1075/ slcs. 55 
ISK = Iso suomen kielioppi ['Comprehensive grammar of Finnish’]. Auli Hakulinen (päätoim.), Maria Vilkuna, Riitta Korhonen, Vesa Koivisto, TarjaRiitta Heinonen, Irja Alho. SKS:n toimituksia 950. Helsinki: Suomalaisen Kirjallisuuden Seura.

Laakso, Johanna 2001. The Finnic languages. - Östen Dahl, Maria KoptjevskajaTamm (Eds.). Circum-Baltic Languages, Volume 1: Past and Present. Studies in Language Companion Series 54. Amsterdam/Philadelphia: John Benjamins, clxxix-ccxii. https://doi.org/10.1075/slcs.54.09laa

Larjavaara, Matti 1986. Itämerensuomen koillisryhmän synkretistiset paikallissijat ['The syncretic local cases in northeastern Finnic']. - Virittäjä 90 (4), 413-427.

Mazzitelli, Lidia 2017. Predicative possession in the languages of the CircumBaltic Area. - Folia Linguistica 51 (1), 1-60. https://doi.org/10.1515/flin2017-0001

McAnallen, Julia 2011. Predicative possession in Old Church Slavic Bible translations. - Eirik Welo (Ed.). Indo-European Syntax and Pragmatics: Contrastive Approaches. Oslo Studies in Language 3 (3). Oslo: University of Oslo, $155-172$.

Novak, Irina 2016. Tverskie dialekty karel'skogo jazyka: fonetika, fonologija. Petrozavodsk: Karel'skij naučnyj centr RAN.

Õispuu, Jaan 1994. Karjala keelesaarte sõnamuutmissüsteem ['Inflectional system of Karelian enclaves']. Tallinna pedagoogikaülikooli toimetised Humaniora A1. Tallinn: Tallinna Pedagoogikaülikool.

Palmeos, Paula 1962. Karjala Valdai murrak ['The Valdai dialect of Karelian']. Eesti NSV Teaduste Akadeemia Emakeele Seltsi toimetised 5. Tallinn: Eesti NSV Teaduste Akadeemia.

Ravila, Paavo 1941. Über die Verwendung der Numeruszeichen in den uralischen Sprachen. - Finnisch-Ugrische Forschungen 27, 1-136.

RG = Švedova, Natalija et al. 1980/2005. Russkaja grammatika ['Grammar of Russian']. Moskva: Nauka/Institut russkogo jazyka imeni V. V. Vinogradova RAN.

Rjagoev, Vladimir 1977. Tikhvinskij govor karel'skogo jazyka ['The Tikhvin dialect of Karelian']. Leningrad: Nauka.

Sarhimaa, Anneli 1999. Syntactic Transfer, Contact-Induced Change, and the Evolution of Bilingual Mixed Codes: Focus on Karelian and Russian Language Alternation. Studia Fennica Linguistica 9. Helsinki: Suomalaisen Kirjallisuuden Seura. 
Seržant, Ilja 2015. Dative experiencer constructions as a Circum-Baltic isogloss. - Peter Arkadiev, Axel Holvoet, Björn Wiemer (Eds.). Contemporary Approaches to Baltic Linguistics. Trends in Linguistics: Studies and Monographs 276. Berlin: De Gruyter, 325-348. https://doi. org/10.1515/9783110343953-009

Seržant, Ilja 2016. External possession and constructions that may have it. - STUF 69 (1), 131-169. https://doi.org/10.1515/stuf-2016-0006

Wiik, Kalevi 2004. Karjalan kielen murteet: kvantitatiivinen tutkimus ['Karelian dialects: quantitative analysis']. - Piret Klesment (Ed.). Uralistika müüdid ja faktid = Myths and facts in Uralistics. Finno-Ugristica 26. Tartu: Tartu ülikool uurali keelte haru, 239-302.

Zajkov, Pëtr 1999. Grammatika karel’skogo jazyka (fonetika i morfologija) [‘Grammar of Karelian: phonetics and morphology']. Petrozavodsk: Periodika.

Zaikov, Pekka 2013. Vienankarjalan kielioppi ['The grammar of Viena Karelian']. Helsinki: Karjalan Sivistysseura.

\section{Nicklas N. B. Oranen}

PL 24 (Unioninkatu 40), 00014 Helsinki, Finland

nicklas.oranen@helsinki.fi 


\title{
Tverinkarjalan adessiivisijan käytöstä
}

\author{
NICKLAS ORANEN
}

Helsingin yliopisto

Tämä tutkimus on deskriptiivinen kuvaus adessiivisijan käytöstä uhanalaisessa ja vaillinaisesti dokumentoidussa tverinkarjalan kielessä. Tutkimus ei pelkästään anna yleiskatsausta kyseisen sijamuodon monenlaisista toiminnallisista käytöistä, vaan vertailee myös käyttöä suomen, viron ja venäjän kieliin. Adessiivisija on historiallisesti yhdistynyt ulkosijainteihin, mutta sijaa käytetään nykyään myös ajan, välineen, omistajan, saajan tai hyötyjän (datiivi) sekä kokijan ilmaisemiseen. Näiden käyttöjen lisäksi tverinkarjalan adessiivisijaa käytetään jopa suorien ja muiden objektien merkinnässä. Adessiivisijan temporaaliset, instrumentaaliset ja possessiiviset funktiot ovat kehittyneet itämerensuomalaisissa kielissä jo varhain, joten tverinkarjalan, suomen ja viron kielten samanlaisuus tässä suhteessa ei ole yllättävää. Mielenkiintoisempi on tverinkarjalan adessiivisijan yhdenmukainen käyttö datiivin funktiossa tai kokijan ilmaisemiseen. Näiden funktioiden yhtenäinen merkintä selittyy sekä sillä, että erillinen allatiivisija funktioineen on sulautunut adessiiviin, että venäjän kielen vaikutuksella. On huomattavaa, että funktioiden adessiivimerkintä vastaa täysin venäjän datiivimerkintää, kun taas näiden funktioiden merkintä on monipuolisempi suomen ja viron kielissä. Venäjän vaikutus näkyy myös tverinkarjalan adessiivisijan käytössä muutamien verbien objektien merkinnässä, mikä näennäisesti heijastaa sekä venäjän kielen datiivi- että instrumentaalimerkintää. Suomessa ja virossa vastaavat objektit ovat yleensä jossakin muussa sijassa kuin adessiivissa. Tverinkarjalan adessiivisijan monenlaiset käytöt selittyvät toisin sanoen diakronisen kehityksen ja kielikontaktin yhdistymisellä. Tutkimus perustuu kirjoittajan kokoamaan aineistoon, joka on kerätty ja nauhoitettu Tverin alueen Lihoslavlin piirissä, Tolmačin, Vasil'kin, Nazarovon, Zalazinon ja Anankinon kylissä. Sen arvoa lisää se, että tverinkarjalan kielioppia koskevaa julkaistua tutkimusta on vähän verraten muihin karjalan kielen varieteetteihin ja muihin itämerensuomalaisiin kieliin.

Avainsanat: sijamerkintä; adessiivisija; kielikontakti; tverinkarjala; suomi; viro; venäjä 